\title{
White spot syndrome baculovirus (WSBV) detected in cultured and captured shrimp, crabs and other arthropods
}

\author{
Chu-Fang Lo ${ }^{1}$, Ching-Hui Ho ${ }^{1}$, Shao-En Peng ${ }^{1}$, Chau-Huei Chen ${ }^{1}$, Hui-Chen Hsu ${ }^{1}$, \\ Ya-Lin Chiu ${ }^{1}$, Chen-Fang Chang ${ }^{2}$, Kuan-Fu Liu ${ }^{2}$, Mao-Sen Su${ }^{2}$, Chung-Hsiung Wang ${ }^{3}$, \\ Guang-Hsiung Kou ${ }^{1, *}$
}

\author{
${ }^{1}$ Department of Zoology, National Taiwan University, Taipei, Taiwan, ROC \\ ${ }^{2}$ Tung Kang Marine Laboratory, Taiwan Fisheries Research Institute, Tung Kang, Ping Tung, Taiwan, ROC \\ ${ }^{3}$ Department of Plant Pathology and Entomology, National Taiwan University, Taipei, Taiwan, ROC
}

\begin{abstract}
White spot syndrome baculovirus (WSBV) has been found across different shrimp species and in different Asian countries. The detection of WSBV in shrimp with white spot syndrome has already been achieved by means of 1 -step polymerase chain reaction (PCR). In an attempt to establish a more sensitive assay, we evaluated the effect of 2-step amplification with nested primers on the sensitivity of WSBV diagnostic PCR. The sensitivity of the 2-step amplification was $10^{3}$ to $10^{4}$ times higher than that of 1 -step amplification. Using both techniques, we successfully detected WSBV DNA in cultured and captured shrimp, crabs and other arthropods. Cultured Penaeus monodon (black tiger shrimp), P. japonicus (kuruma shrimp), P. penicillatus (red tail shrimp), and Metapenaeus ensis (sand shrimp) displaying white spot syndrome were collected from farms at different localities. One-step amplification of the DNA extracted from these shrimps consistently yielded an expected $1447 \mathrm{bp} \mathrm{PCR} \mathrm{product.} \mathrm{Some} \mathrm{of} \mathrm{the} \mathrm{tested} \mathrm{specimens} \mathrm{of} \mathrm{cul-}$ tured Scylla serrata (mud crab) that exhibited white spot syndrome were positive in 1-step WSBV diagnostic PCR, while others were positive only in 2-step WSBV diagnostic PCR. Use of the 2-step amplification protocol also detected a WSBV-specific DNA fragment in Macrobrachium rosenbergii (the giant freshwater prawn) exhibiting white spot syndrome. We also confirmed that WSBV exists in wild-caught shrimp (P. monodon, P. japonicus, P. semisulcatus and P. penicillatus) and crabs (Charybdis feriatus, Portunus pelagicus and $P$. sanguinolentus) collected from the natural environment in coastal waters around southern Taiwan. Detection of WSBV in non-cultured arthropods collected from WSBV-affected shrimp farms revealed that copepods, the pest crab Helice tridens, small pest Palaemonidae prawn and the larvae of an Ephydridae insect were reservoir hosts of WSBV. The relatedness between WSBV and Thailand's systemic ectodermal and mesodermal baculovirus (SEMBV) is discussed in this paper.
\end{abstract}

KEY WORDS: White spot syndrome - Shrimp viral disease $\cdot \mathrm{PCR} \cdot$ Cultured and non-cultured arthropods

\section{INTRODUCTION}

White spot syndrome baculovirus (WSBV) (Lightner 1996) has been found across different shrimp species and in different Asian countries. The principal clinical sign of the disease associated with this virus is the presence of white spots in the exoskeleton and epidermis of the diseased shrimp. The causative virus itself consists of an enveloped, rod-shaped nucleocapsid. It is extremely virulent, has a wide host range and targets various tissues

\footnotetext{
- Addressee for correspondence.
}

E-mail: ghkou@ccms.ntu.edu.tw
(Chou et al. 1995, Wang et al. 1995, Chang et al. 1996, Lo et al. 1996). The rapid onset and lethality of this disease are remarkable. Based on the histopathology of the affected animals and the characteristics of the virus, WSBV is either identical or closely related to Thailand's systemic ectodermal and mesodermal baculovirus (SEMBV) (Wang et al. 1995, Wongteerasupaya et al. 1995, C. Wongteerasupaya pers. comm.). WSBV infection and its associated mortality is emerging as one of the most significant problems for the global shrimp industry.

The amplification of selected DNA sequences by polymerase chain reaction (PCR) is fulfilling its promise as a powerful diagnostic tool for the identification of 
pathogens (Erlich et al. 1988, Oste 1988). In recent years, a number of researchers have drawn attention to the need for more sensitive diagnostic techniques using 'high-tech' approaches for crustacean viruses (Brock 1992, Lightner et al. 1992. Bruce et al. 1993, 1994, Chang et al. 1993, Mari et al. 1993, 1995, Poulos et al 1994, Wang et al. 1995). In the case of WSBV, we have already developed PCR primers and nucleic acid probes for diagnosis (Lo et al. 1996). The specificity of these WSBV PCR primers has already been established (Lo et al. 1996), and in the present paper we use the more sensitive nested PCR to detect the latent or prepatent carrier state of WSBV infection in shrimp and other arthropod populations collected from shrimp farms or from the natural environment.

\section{MATERIALS AND METHODS}

Oligonucleotide primers for WSBV diagnostic PCR. A nested primer set derived from the sequence of a cloned WSBV Sall 1461 bp DNA fragment (Lo et al. 1996) including $146 \mathrm{~F} 1,5^{\prime}$-ACT ACT AAC TTC AGC CTA TCT AG-3'; 146R1，5'-TAA TGC GGG TGT AAT GTT CTT ACG A-3'; 146F2, 5'-GTA ACT GCC CCT TCC ATC TCC A-3'; 146R2, 5'-TAC GGC AGC TGC TGC ACC TTG T-3'; 146F4, 5'-AGA AGG TTA GCG AAT GGA CTG-3'; and 146R3, 5'-CGA AGA GTA GTG TTA GAA GAG GA-3' was utilized for 1-step or 2-step WSBV diagnostic PCR. Four of these were used in our previous study (Lo et al. 1996).

As described previously (Lo et al. 1996), the quality of the DNA extracted from tested organisms was checked with a primer set amplifying a decapod gene before the application of WSBV diagnostic PCR. For this purpose, 2 primers, 143F (5'-TGC CTT ATC AGC TNT CGA TTG TAG-3', where $N$ represents $G, A$, T or C) and 145R (5'-TTC AGN TTT GCA ACC ATA CTT CCC-3'), derived from a highly conserved region of the 18S rRNA sequence of decapods (Kim \& Abele 1990. Lo et al. 1996) were used.

One-step WSBV diagnostic PCR. Three primer pairs, 146F1/146R1，146F2/146R2 and 146F4/146R3, were used for 1-step WSBV diagnostic PCR. The DNA sample extracted from the muscle of 1 diseased black tiger shrimp naturally infected with WSBV was used as template DNA for demonstrating the specificity and sensitivity of the 3 primer pairs in 1-step WSBV diagnostic PCR. The DNA samples used for amplification totaled $0.1 \mu \mathrm{g}$ in a $100 \mu \mathrm{l}$ reaction mixture containing $10 \mathrm{mM}$ Tris- $\mathrm{HCl}, \mathrm{pH} 8.8$ at $25^{\circ} \mathrm{C}, 50 \mathrm{mM} \mathrm{KCl}, 1.5 \mathrm{mM}$ $\mathrm{MgCl}_{2}, 0.1 \%$ Triton X-100, $200 \mu \mathrm{M}$ of each dNTP, 100 pmol of each primer, 2 units of DynaZyme ${ }^{\mathrm{TM} I I}$ DNA Polymerase (Finnzymes Oy, Riihitontuntie $14 \mathrm{~B}$, FIN-02200 Espoo, Finland). The amplification was per- formed in a AG-9600 Thermal Station (Biotronics Corp. Lowell, MA, USA) for 1 cycle of $94^{\circ} \mathrm{C}$ for $4 \mathrm{~min}, 55^{\circ} \mathrm{C}$ for $1 \mathrm{~min}, 72^{\circ} \mathrm{C}$ for $2 \mathrm{~min} ; 39$ cycles of $94^{\circ} \mathrm{C}$ for $1 \mathrm{~min}$, $55^{\circ} \mathrm{C}$ for $1 \mathrm{~min}, 72^{\circ} \mathrm{C}$ for $2 \mathrm{~min}$, plus a final $5 \mathrm{~min}$ extension at $72^{\circ} \mathrm{C}$ after 40 cycles. Control reactions containing no template DNA were run for all PCR reactions. A portion $(10 \mu \mathrm{l})$ from each of the completed PCR reactions was mixed with $1 \mu \mathrm{l}$ loading buffer and subjected to electrophoresis on $1 \%$ agarose gels containing ethidium bromide at a concentration of $0.5 \mu \mathrm{g} \mathrm{ml}^{-1}$, and visualized by ultraviolet transillumination.

Two-step WSBV diagnostic PCR. The first PCR step was performed as described above with the outer primer pair 146F1 and 146R1. After completion of the first step, $10 \mu \mathrm{l}$ of the reaction mixture was added to $90 \mu \mathrm{l}$ of PCR cocktail containing the inner primer pair, $146 \mathrm{~F} 2$ and 146R2, and this was then subjected to a second step of amplification over the same 40 cycles. For the analysis of PCR products, $10 \mu$ of the final reaction mixture was used.

Evaluation of the effect of 2-step PCR with nested primers on the sensitivity of WSBV diagnostic PCR. The relative sensitivity of 1-step PCR, 2-step PCR, 1step PCR with Southern hybridization and 1-step PCR with dot hybridization was investigated as follows:

First step of amplification: Serially 10 -fold diluted $\left(10^{-1}\right.$ to $\left.10^{-9}\right)$ DNA samples of deproteinized DNA extracted from the muscle of diseased black tiger shrimp naturally infected with WSBV served as template DNA samples in the first step of amplification with the 146F1/146R1 primer set.

Second step of amplification: An aliquot $(10 \mu \mathrm{l})$ of each PCR product yielded in the first step of amplification served as template DNA in the second step of amplification.

One-step PCR with Southern hybridization: Southern hybridization was performed with the gel used to analyze the products yielded in the furst step of amplification. After application of alkali (1.5 M NaCl and $0.5 \mathrm{~N} \mathrm{NaOH})$ to denature the DNA, the gel was neutralized with $1 \mathrm{M}$ Tris ( $\mathrm{pH} \mathrm{7.4)}$ and $1.5 \mathrm{M} \mathrm{NaCl}$ and subsequently transferred to a Hybond- $N$ nylon membrane (Amersham, Little Chalfont, Buckinghamshire, UK) using a Hoefer TE 80 vacuum transfer unit (Hoefer Scientific Instruments, San Francisco, CA, USA) for $60 \mathrm{~min}$. A solution of $20 \times \mathrm{SSC}(1 \times \mathrm{SSC}=150 \mathrm{mM} \mathrm{NaCl}, 15 \mathrm{mM}$ sodium citrate, $\mathrm{pH}$ 7.0) was used as transfer buffer. After crosslinking the DNA with the membrane by UV light, the blot was used for hybridization with a probe derived from the $941 \mathrm{bp} \mathrm{PCR} \mathrm{product} \mathrm{of} \mathrm{a} \mathrm{reaction} \mathrm{mixture} \mathrm{with}$ the $146 \mathrm{~F} 2$ and $146 \mathrm{R} 2$ primers. This probe was nonradioactively labeled with digoxigenin (DIG)-dUTP (Boehringer Mannheim, Germany) by a random priming method. The blot was hybridized at $37^{\circ} \mathrm{C}$ for $16 \mathrm{~h}$ with the DIG-labeled probe, after prehybridization at $37^{\circ} \mathrm{C}$ for 
$12 \mathrm{~h}$ in $50 \%$ formamide, $5 \times \mathrm{SSC}, 1 \mathrm{mM}$ EDTA, $50 \mathrm{mM}$ Tris (pH 8) and $5 \times$ Denhardt's reagent $[0.1 \%$ Ficoll-400, $0.1 \%$ polyvinyl pyrrolidone, $0.1 \%$ bovine serum albumin (BSA)]. After hybridization, detection of the DIG-labeled nucleotides in blots was accomplished using a DIG Luminescent Detection Kit (Boehringer Mannheim). The blot was exposed to Kodak XAR-5 film at $37^{\circ} \mathrm{C}$ for 15 to 30 min to record the chemiluminescent signal.

One-step PCR with dot hybridization: An aliquot $(10 \mu l)$ of each of the completed PCR reactions in the first step amplification was incubated with $16 \mu$ of an alkali solution (1.5 M NaCl, $0.5 \mathrm{~N} \mathrm{NaOH}$ ) and $24 \mu$ of $\mathrm{H}_{2} \mathrm{O}$ at room temperature for 5 to $7 \mathrm{~min}$. After being neutralized with $4 \mu \mathrm{l}$ of neutralization solution $(1.5 \mathrm{M}$ $\mathrm{NaCl}, 1 \mathrm{M}$ Tris, $\mathrm{pH} 7.4$ ) for $10 \mathrm{~min}$, the reaction mixtures were spotted onto Hybond-N nylon paper using a 96-well dot-blot vacuum filtration manifold apparatus (Schleicher and Schuell, Inc. Keene, NH, USA). The blot was rinsed with $2 \times$ SSC. After cross-linking the DNA with the membrane by UV light, the blot was used for hybridization with a DIG-labeled probe derived from the $941 \mathrm{bp}$ PCR product. The procedure for the hybridization and signal detection was the same as that for Southern hybridization.

Detection of WSBV in cultured decapods. Cultured Penaeus monodon (black tiger shrimp), $P$. japonicus (kuruma shrimp), P. penicillatus (red tail shrimp), Metapenaeus ensis (sand shrimp), Macrobrachium rosenbergii (the giant freshwater prawn) and Scylla serrata (mud crab) that displayed white spot syndrome (WSS) were collected at various growth stages, from various geographic regions of Taiwan, and in different seasons. These shrimp specimens were subjected to WSBV diagnostic PCR. From each specimen, 1 pereiopod was excised and placed in a small vial, rapidly frozen in liquid nitrogen and then stored at $-70^{\circ} \mathrm{C}$ until use for PCR template DNA preparation. DNA was isolated following the method described by Lo et al. (1996) with some modification. Briefly, a piece of pereiopod (approx. $100 \mathrm{mg}$ ) was placed directly in a microfuge tube containing $1.2 \mathrm{ml}$ digestion buffer $(100 \mathrm{mM} \mathrm{NaCl}$, $10 \mathrm{mM}$ Tris-HCl, pH 8, 25 mM EDTA, pH 8, 0.5\% Nlauryl sarcosine, $0.5 \mathrm{mg} \mathrm{ml}^{-1}$ proteinase $\mathrm{K}$ ) and crushed with a disposable stick. After incubation at $65^{\circ} \mathrm{C}$ for $1 \mathrm{~h}, 5 \mathrm{M} \mathrm{NaCl}$ was added to adjust the $\mathrm{NaCl}$ concentration of the DNA solution to $0.7 \mathrm{M}$. The solution was then treated with $1 \% \mathrm{~N}$-cetyl N,N,N-trimethylammonium bromide (CTAB) for $10 \mathrm{~min}$ at $65^{\circ} \mathrm{C}$ followed by successive extractions with $1 \times$ volume of chloroform/ isoamyl alcohol once, $1 \times$ volume of phenol 2 to 3 times, and $2 \times$ volume of chloroform/isoamyl alcohol once. The DNA was recovered by ethanol precipitation, dried and resuspended in $0.1 \times$ Tris-ethylenediaminetetraacetic acid $(1 \times \mathrm{TE}=10 \mathrm{mM}$ Tris-base, $1 \mathrm{mM}$ EDTA $2 \mathrm{Na}, \mathrm{pH} 7.6$ ) buffer at $65^{\circ} \mathrm{C}$ for $30 \mathrm{~min}$, before being stored at $4^{\circ} \mathrm{C}$ until use for WSBV diagnostic PCR. The PCR products recovered by ethanol precipitation were further analyzed with HaeIII, HpaII, Rsal and Sa3A I restriction endonucleases.

Detection of WSBV in wild-captured decapods. From July through December 1995, 66 Penaeus monodon (body weight: 59 to $128 \mathrm{~g}$ ), 23 P. japonicus ( 35 to $100 \mathrm{~g}$ ), $32 P$. semisulcatus ( 80 to $127 \mathrm{~g}$ ), and $27 \mathrm{P}$. penicillatus (18 to $39 \mathrm{~g}$ ) in the adult stages and of wild origin were captured from their natural environment in the coastal waters around southern Taiwan. On their arrival at Tung Kang Marine Laboratory, specimens were examined visually and found to be in good health with no evidence of WSS. In order to minimize the effect of stressful conditions which can trigger increased viral replication in the shrimp, excision of 1 pereiopod from each of the specimens was performed immediately, and the excised pereipod was then subjected to 2-step WSBV diagnostic PCR. When the results of the first step of amplification became available $4 \mathrm{~h}$ later, one of the specimens whose pereiopod was positive for WSBV by 1 -step PCR was killed and its tissues were prepared for histological observation using light microscopy as described previously (Chou et al. 1995). The remaining shrimp specimens were maintained in $500 \mathrm{l}$ tanks for a period of further observation.

Detection of WSBV in non-cultured arthropods from shrimp farms. Specimens of copepods, pest crab Helice tridens, small pest Palaemonidae prawn and pupae of an Ephydridae insect were collected from shrimp farms in epizootic areas and subjected to 2 -step WSBV diagnostic PCR in order to ascertain whether WSBV was present in these non-cultured arthropods.

\section{RESULTS}

\section{Oligonucleotide primers and amplicons of WSBV diagnostic PCR}

The relative positions of oligonucleotide primers corresponding to the sequences of the WSBV Sall $1461 \mathrm{bp}$ DNA fragment for WSBV diagnostic PCR and their amplicons are indicated in Fig. 1A. Fig. 1B shows the 1step PCR product primed by 146F1/146R1 (lane 1), 146F2/146R2 (lane 2) and 146F4/146R3 (lane 3) with each lane using the same amount of template DNA isolated from 1 WSBV-infected specimen of black tiger shrimp. The primer pairs achieved higher sensitivity when they yielded shorter amplicons. In the nested protocol for 2-step PCR in this study, 146F1/146R1 was used for outer PCR while 146F2/146R2 was used for inner PCR. However, several other combinations of primer pairs for the nested protocol were tested and also yielded good results (data not shown). 


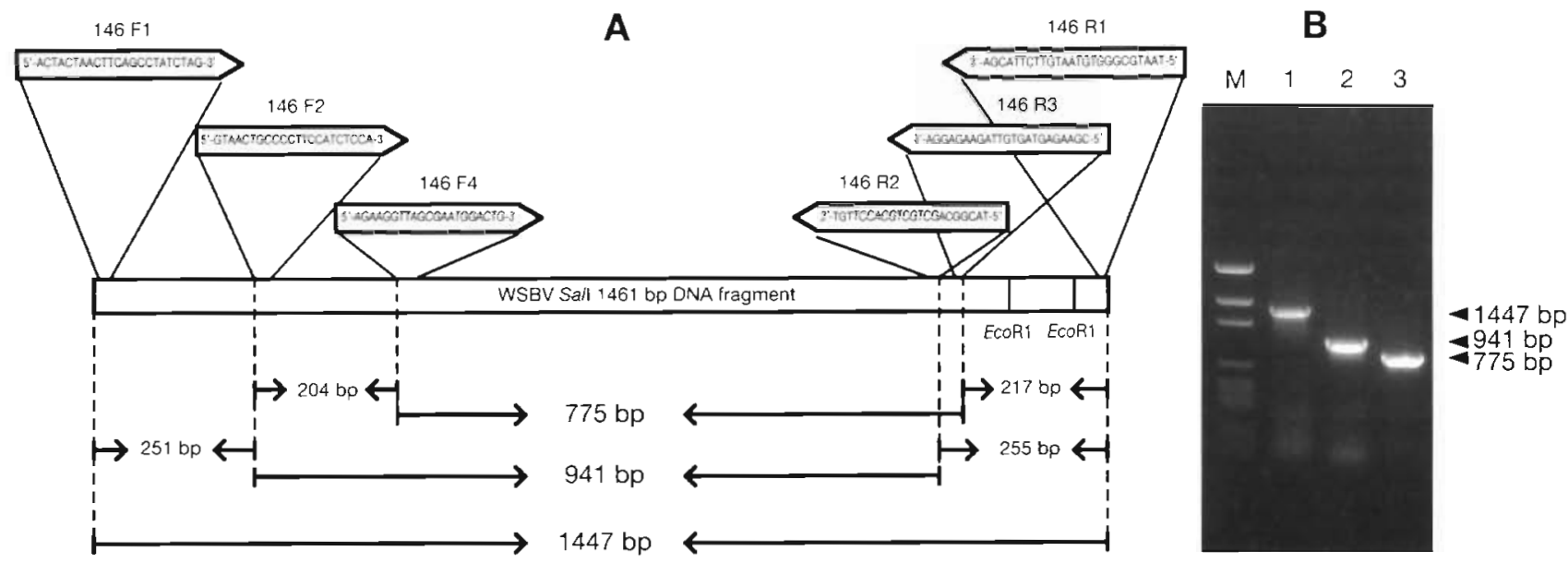

Fig. 1. Primers and amplicons of WSBV diagnostic PCR. (A) Location and sequence of primers for WSBV diagnostic PCR; (B) amplicons primed by 146F1/146R1 (lane 1), 146F2/146R2 (lane 2) and 146F4/146R3 (lane 3). M: pGEM DNA size marker

\section{Evaluation of the effect of 2-step PCR with nested primers on the sensitivity of WSBV diagnostic PCR}

The sensitivity of the 2-step PCR was $10^{3}$ to $10^{4}$ times higher than that of the 1 -step PCR (Fig. 2). The $10 \mu \mathrm{l}$ of completed PCR reaction mixture of the first step of amplification, which served as the DNA source for the second step of amplification, contained some 1447 bp PCR products as well as some excess from the $146 \mathrm{~F} 1 /$ 146R1 primer set. Because of this, the DNA samples that yielded a visible band of $1447 \mathrm{bp}$ fragment in the first step of amplification usually yielded 2 visible bands (1447 and $941 \mathrm{bp}$ ) in the second step of amplification (Fig. 2B). The sensitivity of 2-step PCR was also higher than that of 1-step PCR with Southern or dot hybridization, by a factor of about $10^{2}$ to $10^{3}$ (Fig. 2B, C, D).

\section{Detection of WSBV in cultured decapods}

WSS was found in 4 major cultured species of marine shrimp, i.e. Penaeus monodon, P. japonicus, $P$. penicillatus and Metapenaeus ensis (Fig. 3). Except for $P$. penicillatus, WSS was readily observed in diseased cultured shrimp, with the white spots being quite marked (Fig. 3A, B, D). In diseased $P$. penicillatus, however, the white spots were not easily seen (Fig. 3C) until after the carapace had been removed. One-step amplification of WSBV DNA from the DNA samples of shrimp that displayed WSS consistently yielded a 1447 bp PCR product as shown in the left panel of Fig. 4. The results confirmed the presence of a relatively large amount of WSBV in the tested specimens. Interestingly, we found that the amount of the WSBV in shrimp from the same pond collected at the same

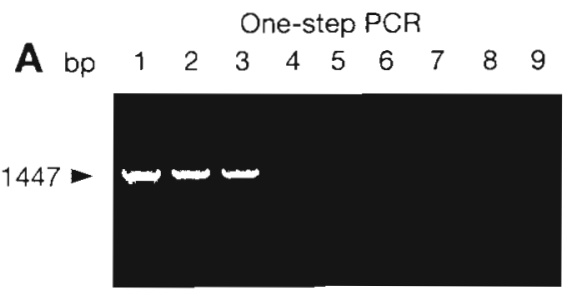

Two-step PCR

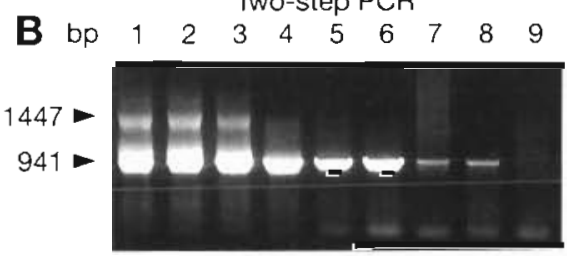

One-step PCR+Southern hybridization

C l b $\begin{array}{lllllllll}1 & 2 & 3 & 4 & 5 & 6 & 7 & 8 & 9\end{array}$

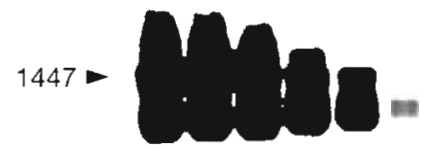

D One-step PCR+dot hybridization

$\begin{array}{llllllll}1 & 2 & 3 & 4 & 5 & 6 & 8 & 9\end{array}$

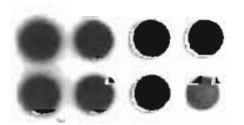

Fig. 2. Detection of WSBV DNA in serially 10-fold diluted DNA extracted from naturally infected black tiger shrimp by (A) 1-step PCR; (B) 2-step PCR; (C) 1-step PCR with Southern hybridization; and (D) 1-step PCR with dot hybridization. (A) 1-step PCR using 146F1 and 146R1 primer pair; (B) 2-step (nested) PCR using 146F1 and 146R1 as an outer primer pair, and $146 \mathrm{~F} 2$ and 146R2 as an inner primer pair; (C) Southern hybridization after 1 -step PCR using a DIG-labeled 146F2146R2 probe; (D) dot hybridization after 1-step PCR using a DIG-labeled $146 \mathrm{~F} 2-146 \mathrm{R} 2$ probe. Lanes 1 to 9 correspond to $10^{-1}$ to $10^{-9}$ dilution of infected shrimp DNA. PCR products indicated by arrowbeads 

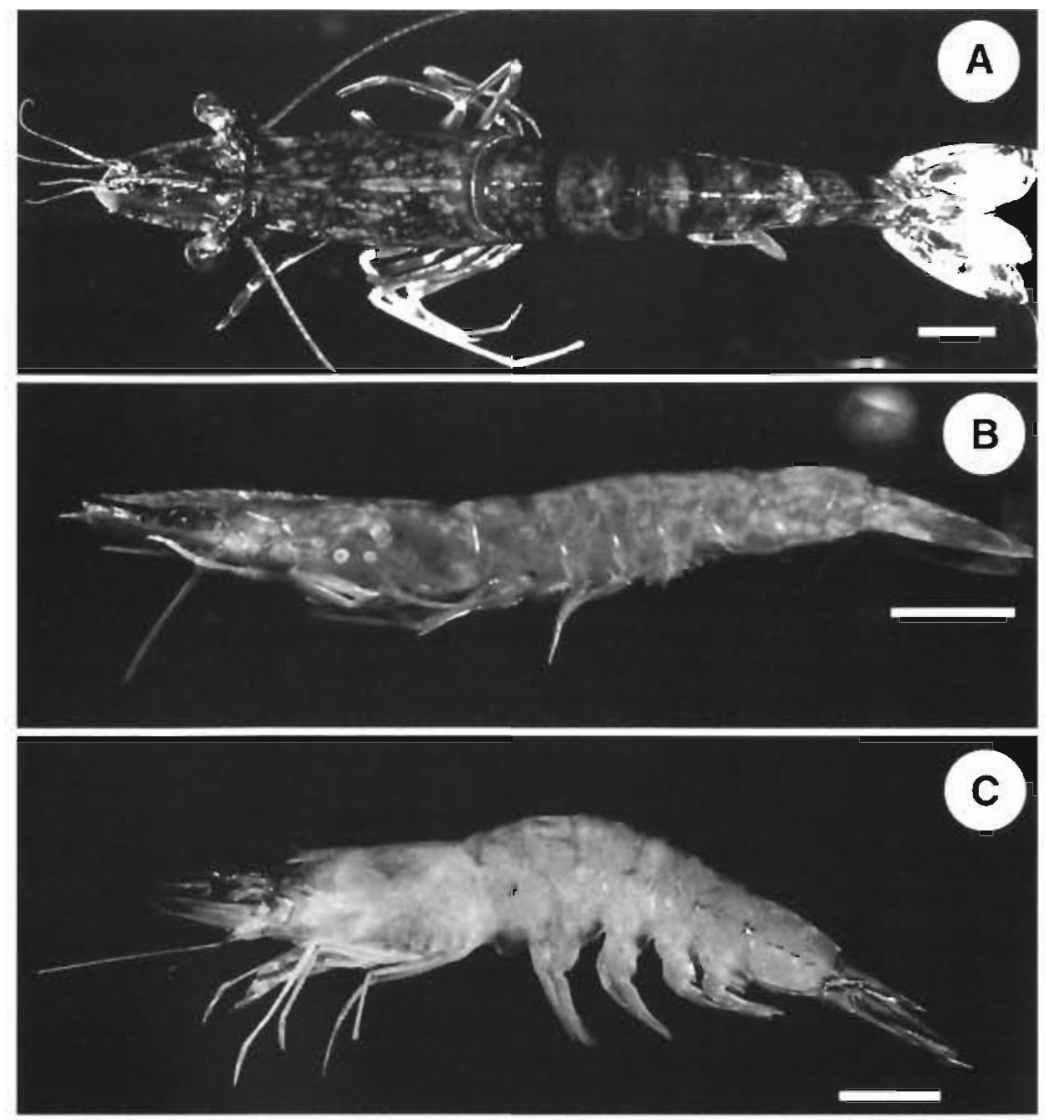

D

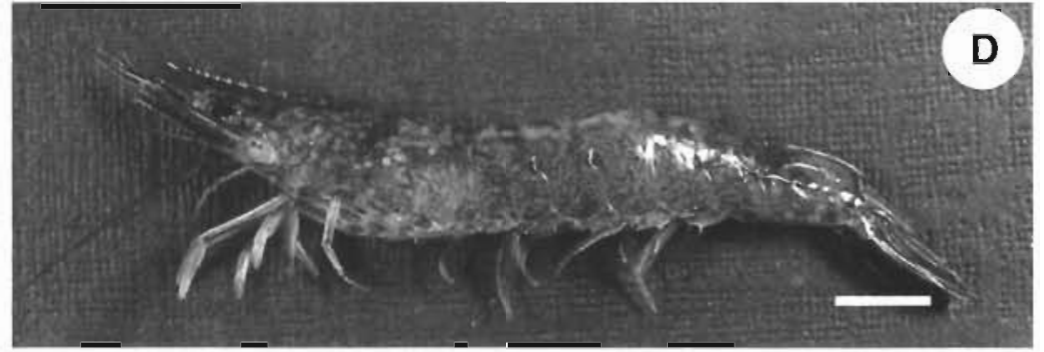

Fig. 3. Cultured marine shrimp with white spot syndrome. (A) Penaeus monodon. (B) P. japonicus, (C) $P$ penicillatus, (D) Metapenaeus ensis. Scale bars $=1 \mathrm{~cm}$

time was similar; this is evidenced by the similar intensity of their PCR product bands as shown in the left panel of Fig. 4, in which 2 specimens of each shrimp species collected from the same pond at the same time are shown. No differences were observed in the restriction profiles of PCR products yielded by $P$. monodon, $P$. japonicus, $P$. penicillatus, and Metapenaeus ensis, analyzed with HaeIII, HpaII, RsaI and Sau3AI restriction endonucleases (Fig. 4, right panel), which indicates the close relatedness of WSBV found in the different species of shrimp collected from various geographic regions of Taiwan and in different seasons.

The WSS displayed by the cultured marine crab Scylla serrata was readily seen in pereiopods rather than in the carapace. When these crabs were subjected to WSBV diagnostic PCR, some tested specimens gave a positive result in the first step of amplification, while others gave a positive result only after reamplification. Unexpectedly, all tested specimens of the cultured freshwater prawn Macrobrachium rosenbergii with WSS gave WSBV-positive results only
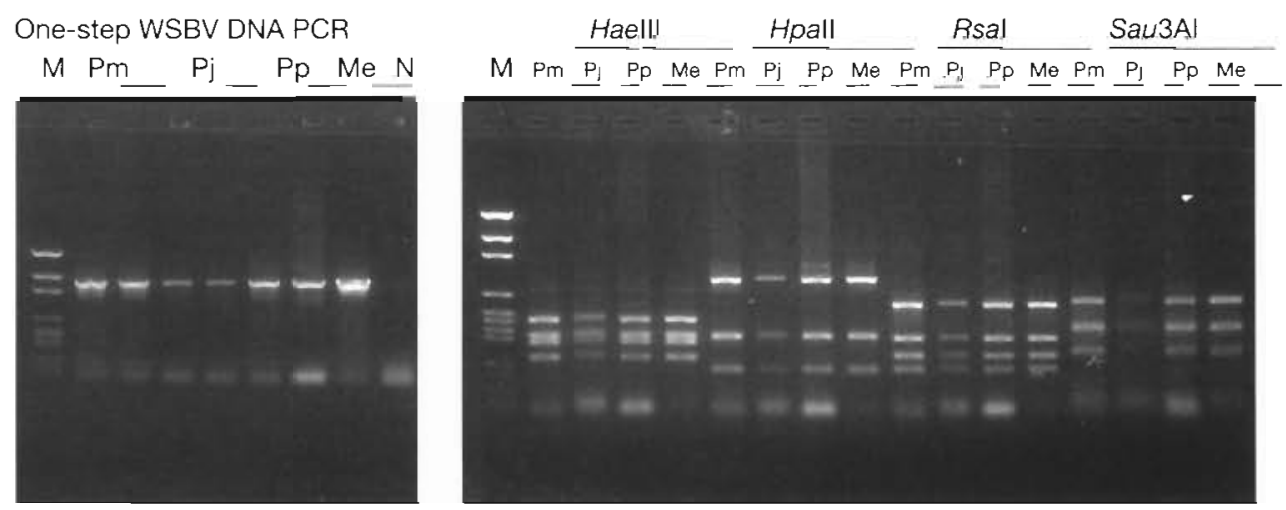

Fig. 4. WSBV-specific DNA fragments amplified from template DNA samples prepared from cultured marine shrimp Penaeus monodon (Pm), P. japonicus ( $\mathrm{Pj}$ ), P. penicillatus (Pp), and Metapenaeus ensis (Me) that displayed marked white spot syndrome. Two specimens for each species of $P$. monodon, $P$. japonicus, and $P$. penicillatus were collected from the same pond at the same time. Left panel: 1-step WSBV PCR products. Right panel: result of the PCR products analyzed with HaeIlI, HpaII, RsaI and Sau3AI restriction endonucleases. $M$ : pGEM DNA size marker; $N$ : template-free control reaction 
A

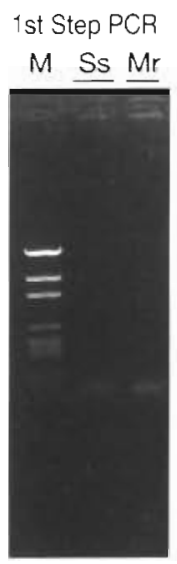

B 2nd Step PCR $M$ Ss $\mathrm{Mr}$
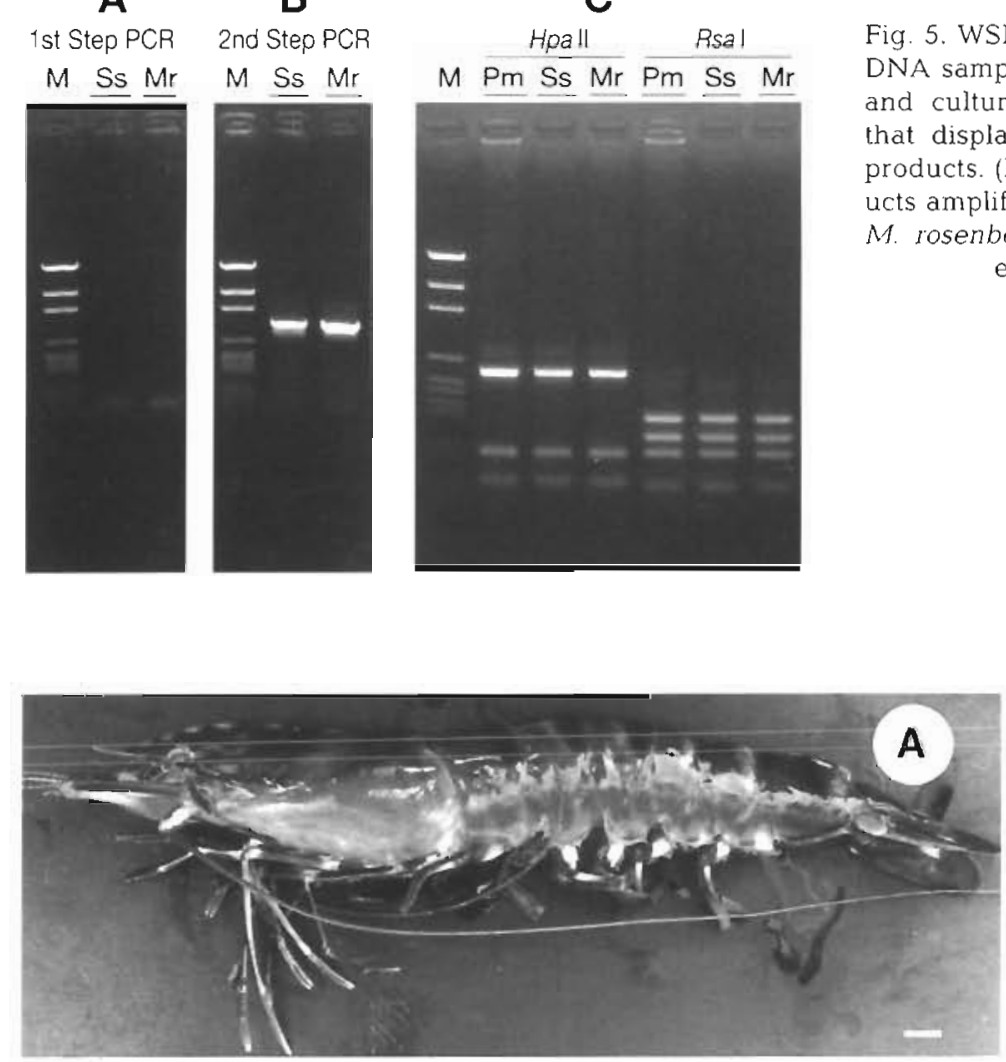

B
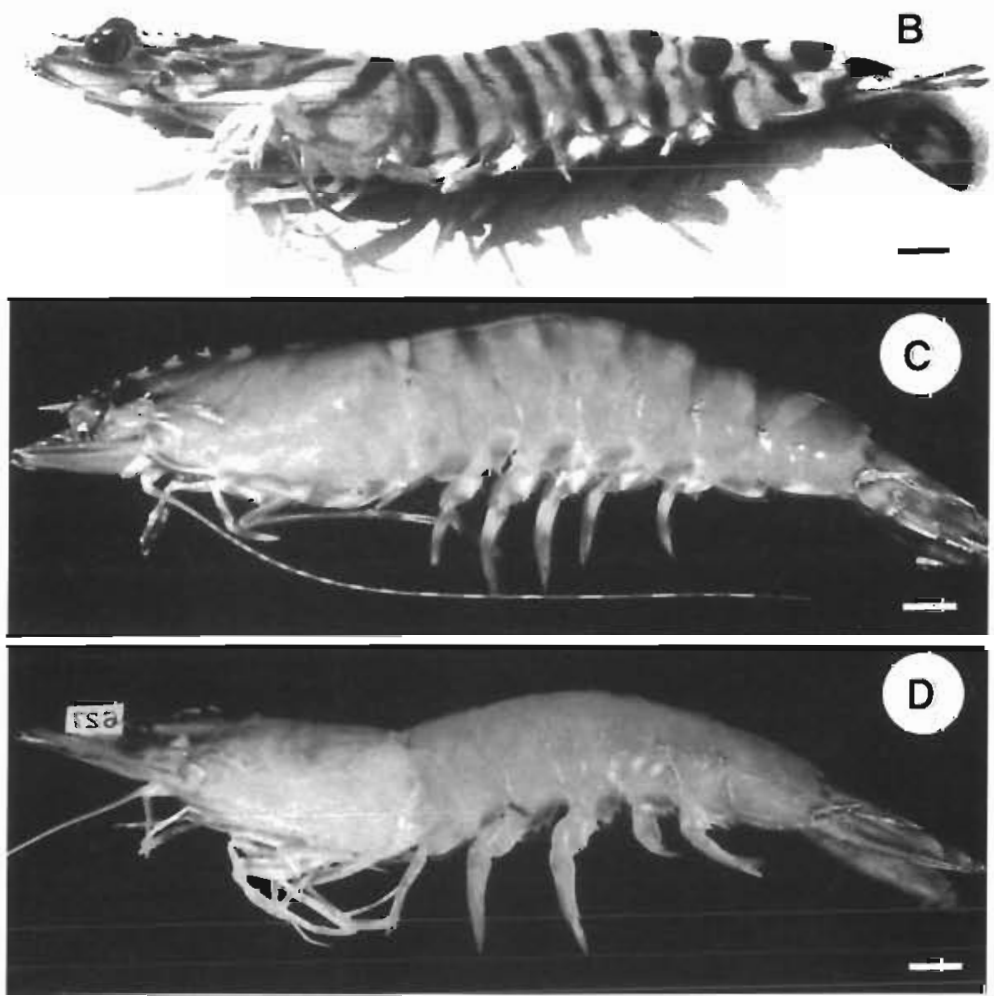

Fig. 6. (A) Penaeus monodon, (B) P. japonicus, (C) P. semisulcatus, and (D) $P$. penicillatus captured from coastal waters near southern Taiwan. Scale bars $=1 \mathrm{~cm}$ after the second step of amplification, in which they yielded a 941 bp PCR fragment. However, analysis of this PCR product with Hpall and RsaI restriction endonucleases showed similar restriction profiles to those of the $941 \mathrm{bp}$ fragments yielded by $P$. monodon and the mud crab S. serrata (Fig. 5).

\section{Detection of WSBV in wild-captured decapods}

Captured specimens of apparently healthy, wild Penaeus monodon, $P$. japonicus, $P$. semisulcatus and $P$. penicillatus were immediately tested by PCR analysis upon their arrival at Tung Kang Marine Laboratory. The signs of WSS, even when present, were not readily seen in these examined specimens (Fig. 6).

The results of PCR analysis (Table 1) indicated the presence of WSBV in all 4 of the species investigated. Of the 66 Penaeus monodon collected 50 were positive by 2 step WSBV diagnostic PCR and 22 of these were positive in the first step of amplification. The 1-step WSBV PCR-positive individuals usually died within 1 to $3 \mathrm{~d}$ after arrival at Tung Kang Marine Laboratory. Small white spots were observed on carapaces removed from the carcasses. Tissues from selected specimens of $P$. monodon which were positive by 1 -step PCR exhibited the typical histopathological changes caused by WSBV infection in tissues of the gill, the stomach, the pleopods and the lymphoid organ. Cells with characteristic hypertrophied nuclei were readily seen in these tissues (Fig. 7).

Occasionally, crabs were found amongst the captured shrimp, specifically Charybdis feriatus (1 specimen), Portunus pelagicus (2 specimens) and $P$. sanguinolentus 
Table 1. Results of 2-step WSBV diagnostic PCR with adult, captured Penaeus monodon, P. japonicus, P. semisulcatus and $P$ penicillatus. Values represent no. of shrimp positive in the first and second step PCR per no. of shrimp examined

\begin{tabular}{|lcccc|}
\hline WSBV diagnostic PCR & P. monodon & P.japonicus & P. semisulcatus & P. penicillatus \\
\hline 1-step PCR & $22 / 66$ & $5 / 23$ & $0 / 32$ & $0 / 27$ \\
2-step PCR & $50 / 66$ & $14 / 23$ & $2 / 32$ & $3 / 27$ \\
\hline
\end{tabular}

(1 specimen). All of these crabs were positive in the second step of 2-step WSBV diagnostic PCR.

\section{Detection of WSBV in non-cultured arthropods from shrimp farms}

Copepods, pest crab Helice tridens, small pest Palaemonidae prawn, and pupae of an Ephydridae insect were coilected from shrimp farms in epizootic areas of WSBV infection (Fig. 8). Template DNA samples were prepared from the pereiopods of 15 specimens of small Palaemonidae pest prawns and 9 specimens of $H$. tridens pest crab. They were also prepared from 10 coarctate larvae removed from the protective case of Ephydridae pupae and 6 pooled, pelleted samples of copepods. These samples were subjected to 2-step WSBV diagnostic PCR. As shown in Table 2, WSBVpositive cases were found in copepods, pest crab, pest prawn and insects which had been recently (within half a day) collected from shrimp farms. Four out of 10 Ephydridae pupae, 2 out of the 6 pooled samples of copepods, 10 out of 15 pest prawn specimens and 4 out of 11 pest crab specimens were positive by 1 -step WSBV diagnostic PCR. Thus copepods, pest crab $H$. tridens and small pest Palaemonidae prawn as well as an Ephydridae insect are evidently reservoir hosts for WSBV in shrimp culture facilities.
Fig. 7. Penaeus monodon. (A) Gill, (B) stomach, (C) pleopod, and (D) lymphoid organ of a selected 1-step WSBV PCRpositive $P$ monodon exhibiting the typical histopathological changes caused by WSBV attacks. Degenerated cells characterized by hypertrophied nuclei (arrows) are readily seen in these tissues. Scale bars $=20 \mu \mathrm{m}$
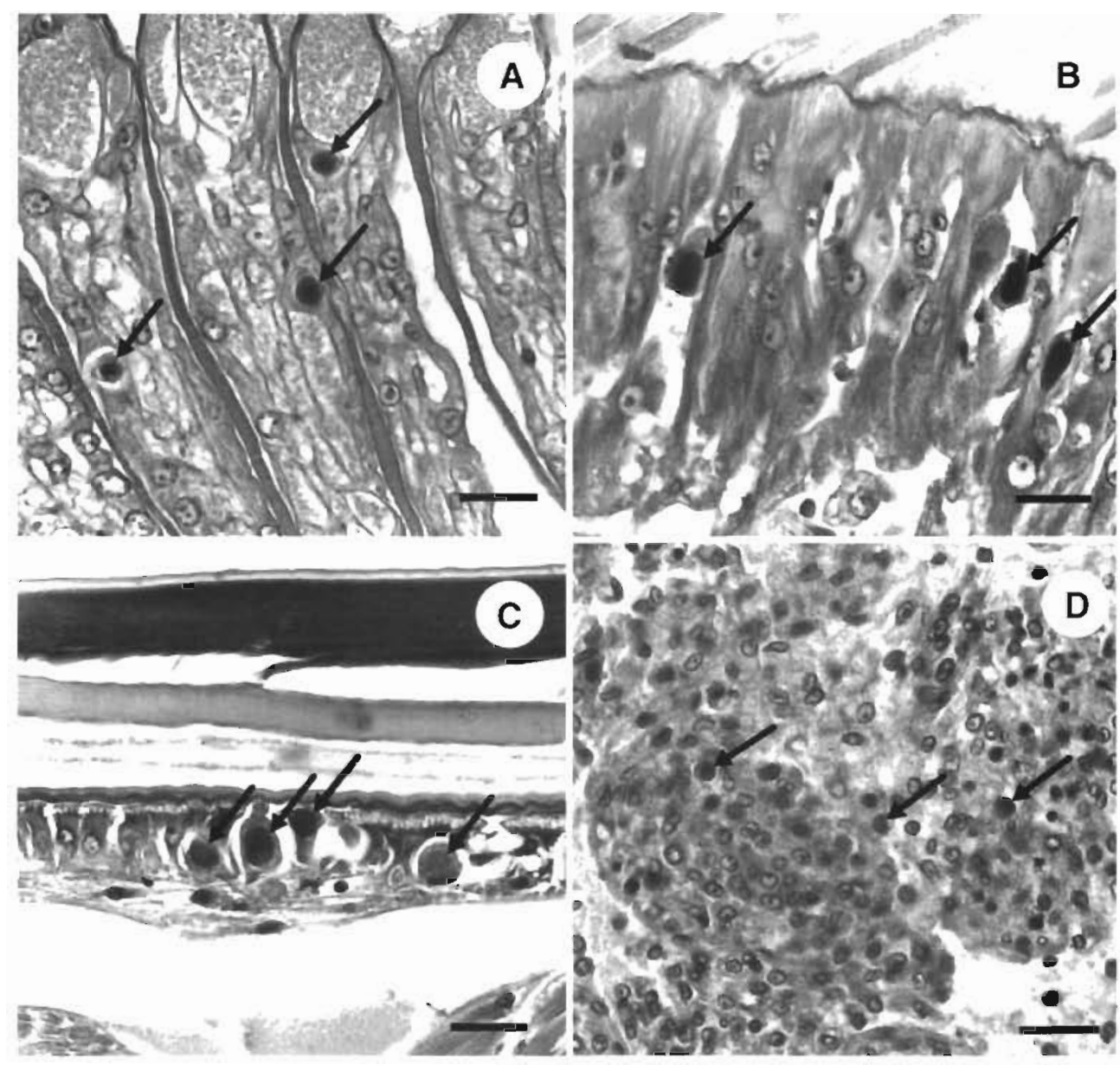

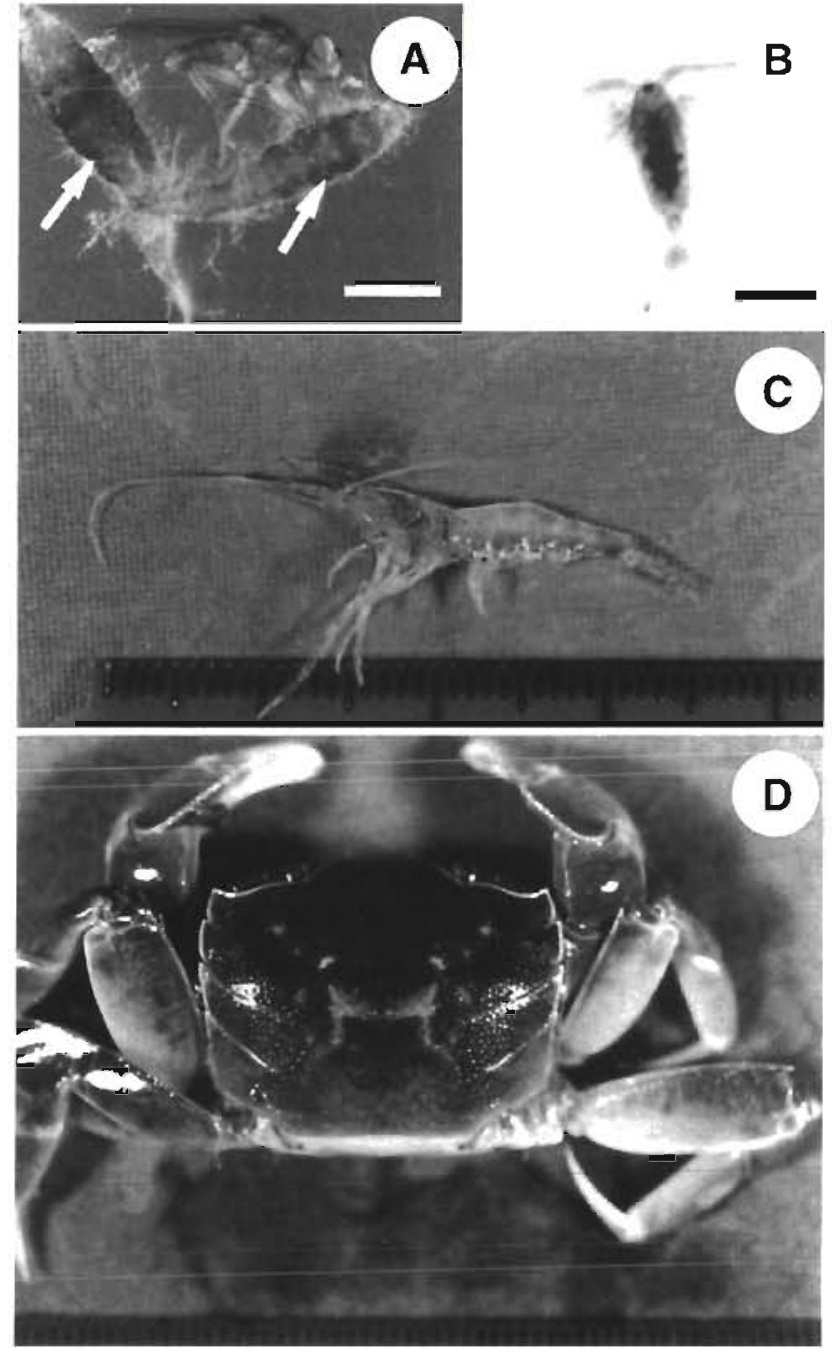

Fig. 8. (A) Insect (family: Ephydridae), (B) copepod (subclass: Copepoda, Schmackeria dubia), (C) pest prawn (family: Palaemonidae, Exopalaemon orientis.), and (D) pest crab (Helice tridens) collected from shrimp farms in epizootic areas of WSBV infection. White scale bar in (A) $=3 \mathrm{~mm}$; black scale bar in $(B)=0.5 \mathrm{~mm}$. Arrows indicate the pupae of an Ephydridae insect

\section{DISCUSSION}

The specificity of the primers used here as well as the standardization of preparation procedures for template DNA and its quality control have been described previously (Lo et al. 1996). Furthermore, in pilot studies of WSBV tissue tropism in various decapods using histopathological examination, in situ hybridization assay and transmission electron microscopic observation, the preliminary data show that in most cases, a positive PCR result coincides with WSBV histopathology and the presence of WSBV positive cells as revealed by in situ hybridization (data not included in this manuscript). Nonetheless, although 2-step PCR is very sensitive and reliable, there is a need for stringent controls to eliminate the increased chance of false positives. Therefore, in addition to a template-free reagent control reaction, a PCR reaction with a template is run as a supplementary negative control for all PCR reactions (Lo et al. 1996). In the present study, a sample from a previously prepared batch of WSBV-free shrimp abdominal muscles $(100 \mathrm{mg}$ in each vial; stored at $-70^{\circ} \mathrm{C}$ ) was always included in our DNA extraction samples (data not shown). This provided some reassurance that positive results did not arise from contamination during processing, but false positives and physical environmental contamination are complex issues that will be discussed more fully in papers currently in preparation.

WSBV was previously classified by Wang et al. (1995) as the genus Non-Occluded [sic] Baculovirus $(N O B)$ of the subfamily Nudibaculovirinae of the family Baculoviridae in accordance with the fifth report of the International Committee on the Taxonomy of Viruses (ICTV) (Francki et al. 1991). In the sixth report of the ICTV, however, the subfamily Nudibaculovirinae and the genus $N O B$ are not listed (Murphy et al. 1995). The 2 included genera of the family Baculoviridae are Nucleopolyhedrovirus and Granulovirus, and WSBV is unlikely to belong to either. The insect viruses Oryctes rhinoceros virus (OrV) and Heliothis zea virus $1(\mathrm{HzV}-1)$, which were previously classified as nonoccluded members of the family Baculoviridae, have now been placed in the list of unassigned invertebrate viruses. Although more than a dozen nonoccluded baculoviruses have been found associated with a number of arthropod hosts, including Insecta, Arachnida and Crustacea, very little is known about their molecular biology (Sano et al. 1981, Lester et al. 1987, Johnson 1988, Johnson \& Lightner 1988, Burand 1991, Crawford 1994,

Wang et al. 1995, Wongteerasupaya
Table 2. Results of 2-step WSBV diagnostic PCR in copepods (subclass: Cope poda), pest crab Heljce tridens, small pest prawn (family: Palaemonidae) and an insect (family: Ephydridae) collected from shrimp farms in epizootic areas of WSBV infection. Values represent no. of specimens positive in the first and second step PCR per no. of specimens examined

\begin{tabular}{|lcccc|}
\hline WSBV diagnostic PCR & Insect & Copepod & Pest prawn & Pest crab \\
\hline 1-step PCR & $4 / 10$ & $2 / 6$ & $10 / 15$ & $4 / 11$ \\
2-step PCR & $8 / 10$ & $4 / 6$ & $12 / 15$ & $5 / 11$ \\
\hline
\end{tabular}


et al. 1995). To date, it is not clear whether WSBV and other nonoccluded baculoviruses should in fact be included in the Baculoviridae or not. Genome sequencing, genome organization, gene order, strategy of replication and other genetic considerations of insect and crustacean nonoccluded baculoviruses, which are becoming increasingly important as viral taxonomic criteria (Murphy et al. 1995), are in urgent need of further study before the taxonomic status of these viruses can be decided. Notwithstanding the uncertainty in the taxonomic position of nonoccluded baculoviruses, in a recently published handbook of pathology and diagnostic procedures for diseases of penaeid shrimp (Lightner 1996), the present virus is called white spot syndrome baculovirus (WSBV). Consequently, in the interests of nomenclaturial consistency, this is the name that we have used here.

Wang et al. (1995) demonstrated that negatively stained preparations of WSBV virions frequently had tail-like projections extending from one end, that the nucleocapsid components form parallel cross-striations which are perpendicular to the longitudinal axis of the nucleocapsid, and that the full length of WSBV genomic DNA was longer than $150 \mathrm{kbp}$. WSBV is very close to SEMBV from Thailand in terms of viral morphology (size, bacilliform with a tail, banding of nucleocapsid) and type and size of genome. WSBV EcoR I and BamH I restriction profiles (authors' unpubl. data) were also found to be similar to those published for Thailand's SEMBV (Wongteerasupaya et al. 1995). [In this regard, please note that Thailand's SEMBV group has informed us that the names of the restriction enzymes were inadvertently transposed in the caption to Fig. 4 of their article in Diseases of Aquatic Organisms (Vol. 21, p. 75) (C. Wongteerasupaya pers. comm.).] Thus, SEMBV and WSBV are at least very similar if not identical.

In several respects including viral morphology and genome size, WSBV is distinct from the $\mathrm{Hz}-1$ virus but shares some characteristics with the Oryctes rhinoceros virus, a pathogenic virus of invertebrates, which infects coleopteran insects in the family Scarabaeidae (Burand 1991, Crawford 1994, Murphy et al. 1995, Wang et al. 1995, Wongteerasupaya et al. 1995). Nevertheless, WSBV and OrV are alike only to a certain extent, and their very similarity raises questions. What, if any, is the relationship between insect viruses and crustacean viruses? Are these viral agents present in insects and crustaceans in the natural environment? Could interactions between insects and cultured crustaceans contribute to the increased number of outbreaks of shrimp viral disease? Most immediately, is it possible that insects or other non-cultured animals act as reservoir hosts of crustacean viruses or vice versa? In the present study, we have shown PCR evidence of
WSBV in the pupae of an Ephydridae insect. It was also detected in copepods, another non-decapod. So far, it is not clear whether WSBV replicates in either insects or copepods, or whether it can cause disease in them. The interaction between cultured shrimp and insects or other reservoir hosts that inhabit farms, estuaries and coastal waters are of great interest. The dynamics involved may be very complex but understanding them should help prevent viral diseases.

We found that about $40 \%$ of the pest crab Helice tridens and Palaemonidae prawn collected from epizootic areas of WSBV infection were positive for WSBV by 1 -step diagnostic PCR. These animals were obtained from farms where mass mortality of cultured shrimp had occurred and only very few cultured shrimp still survived. We carefully examined a large number of carapaces removed from Palaemonidae specimens immediately after being collected from these farms and all of them were exceptionally clear. Thus, these pest species are very likely asymptomatic carriers of WSBV in farms. However, when transferred to the laboratory, the number of the specimens positive by 1 -step diagnostic PCR increased over time (data not shown) and all died within a few days. White spot syndrome was readily observed in these moribund specimens. Thus, under stressful conditions, WSBV was able to cause disease in these pest prawns.

In Taiwan, there are 3 different sources of salt water for shrimp farms: oceanic surface water, beach sandfiltered sea water and water from saline wells (Chen 1990). Underground sea water (i.e. that from saline wells) is the most popular water source for small shrimp culture ponds in Taiwan while large earthen ponds tend to use oceanic surface water which is exchanged through canals by gravity flow during high and low tides. Beach sand-filtered sea water and underground water systems are normally pest-free, and the threat of pathogens is much reduced. By contrast, there is a high risk that tidal input can introduce pathogens, microscopic eggs and larvae of such pests as Palaemonidae prawn and pest crabs. We have shown here that these pests may be major reservoir hosts of WSBV and it is now important to continue to examine these species in greater detail (histology, in situ hybridization, bioassays, etc.) to determine to what extent they might represent a real threat to the shrimp aquaculture industry. Furthermore, the direct discharge of water from shrimp culture systems into drainage canals can release WSBV carriers and WSBV itself into coastal waters. This could have a severe negative impact on natural decapod populations and other susceptible animals. A number of wild shrimp populations now also carry infectious hypodermal and hematopoietic necrosis virus (IHHNV) (Lotz 1992), possibly as a consequence of nearby shrimp culture 
activities (Fulks \& Main 1992). It is clear that water supply systems and poor management of the culture and waste water can speed the spread of the virus and have a severe negative impact on the natural environment.

It was disappointing to learn that WSBV was present in wild populations of Penaeus monodon, P. japonicus, $P$. semisulcatus, and $P$. penicillatus. Several possible factors might explain the high prevalence of WSBV infection in $P$. monodon when compared to the other species studied. First, the black tiger shrimp frequents waters of less than $30 \mathrm{~m}$ in depth. Unlike many of the other penaeid shrimp, it does not bury itself in sand but stays on the surface of the substrate (Chen 1990). Consequently, it has more chance of being exposed to WSBV in coastal waters polluted by the discharge from affected ponds. Secondly, many parts of Asia, including Taiwan, have been conducting programs of releasing hatchery-reared postlarvae (Fulks \& Main 1992) or $30 \mathrm{~g}$ female shrimp (Chen 1990) into coastal waters in order to replenish natural shrimp stocks. Before we have effective diagnostic tools for all the known shrimp viruses and can certify shrimp stocks, the practice of releasing farmed shrimp into the natural environment should be avoided because it may have a negative impact on natural stocks. Conversely, the widespread use of captured broodstock of the black tiger shrimp or kuruma shrimp to produce fry for stocking farms may contribute to the viral disease problems faced by the shrimp culture industry in Taiwan and many other areas.

Acknowledgements. This work was supported by the Council of Agriculture under grant no. 85-AST-1.1-FAD-49(27)A, 85-AST-1.1-FAD-49(27)B and the National Science Council under grant no. NSC85-2311-B002-012-B04. We are indebted to Dr Jung-Yaw Lin, Institute of Biochemistry, College of Medicine, National Taiwan University for his constructive suggestions, and for access to data bases. We thank Dr I-Chiu Liao, Director General, Taiwan Fisheries Research Institute (TFRI), for his constructive suggestions. We thank Dr Timothy William Flegel of Mahidol University for numerous discussions on Thailand's SEMBV. We are indebted to Mr Paul Barlow for his helpful criticism of the manuscript.

\section{LITERATURE CITED}

Brock JA (1992) Current diagnostic methods for agents and diseases of farmed marine shrimp. In: Fulks W, Main KL (eds) Diseases of cultured penaeid shrimp in Asia and the United States. The Oceanic Institute, Honolulu, HI p $209-232$

Bruce LD, Lightner DV, Redman RM (1994) Comparison of traditional and molecular detection methods for baculovirus penaeid infections in larval Penaeus vannamei. $J$ Aquat Anim Health 6:355-359

Bruce LD, Redman RM, Lightner DV, Bonami JR (1993) Application of gene probes to detect a penaeid shrimp baculo- virus in fixed tissue using in situ hybridization. Dis Aquat Org 17:215-221

Burand J (1991) Molecular biology of the $\mathrm{HzV}-1$ and Oryctes nonoccluded baculoviruses. In: Kurstak E (ed) Viruses of invertebrates. Marcel Dekker, Inc, New York, p 111-126

Chang PS, Lo CF, Kou GH, Lu CC, Chen SN (1993) Purification and amplification of DNA from Penaeus monodontype baculovirus (MBV). J Invertebr Pathol 62:116-120

Chang PS, Lo CF, Wang YC, Kou GH (1996) Identification of white spot syndrome associated baculovirus (WSBV) target organs in the shrimp Penaeus monodon by in situ hybridization. Dis Aquat Org 27:131-139

Chen LC (1990) Aquaculture in Taiwan. The Alden Press, Oxford

Chou HY, Huang CY, Wang CH, Chiang HC, Lo CF (1995) Pathogenicity of a baculovirus infection causing white spot syndrome in cultured penaeid shrimp in Taiwan. Dis Aquat Org 23:165-173

Crawford A (1994) Nonoccluded baculoviruses. In: Webster RG, Granoff A (eds) Encyclopedia of virology. Academic Press, New York, p 133-139

Erlich HH, Gelfand DH, Saiki RK (1988) Specific DNA amplification. Nature 331:461-462

Francki RIB, Fauquet CM, Knudson DL, Brown F (1991) Classification and nomenclature of viruses. Arch Virol (Suppl) 2:1-450

Fulks W, Main KL (1992) Diseases of cultured penaeid shrimp in Asia and the United States. The Oceanic Institute, Honolulu, HI

Johnson PT (1988) Rod-shaped nuclear viruses of crustaceans: hemocyte-infecting species. Dis Aquat Org 5:111-122

Johnson PT, Lightner DV (1988) Rod-shaped nuclear viruses of crustaceans: gut-infecting species. Dis Aquat Org 5: $123-141$

Kim W, Abele LG (1990) Molecular phylogeny of selected decapod crustaceans based on 18s rRNA nucleotide sequences. J Crust Biol 10:1-13

Lester RJG, Doubrovsky A, Paynter JL, Sambhi SK, Atherton JG (1987) Light and electron microscope evidence of baculovirus infection in the prawn Penaeus plebejus. Dis Aquat Org 3:217-219

Lightner DV (ed) (1996) A handbook of pathology and diagnostic procedures for diseases of penaeid shrimp. World Aquaculture Soc., Baton Rouge

Lightner DV, Poulos BT, Bruce L, Redman RM, Mari J, Bonami JR (1992) New developments in penaeid virology: application of biotechnology in research and disease diagnosis for shrimp viruses of concern in the Americas. In: Fulks W, Main KL (eds) Diseases of cultured penaeid shrimp in Asia and the United States. The Oceanic Institute, Honolulu, HI, p 233-256

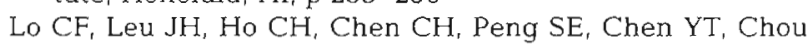
CM, Yeh PY, Huang CJ, Chou HY, Wang $\mathrm{CH}$, Kou GH (1996) Detection of baculovirus associated with white spot syndrome (WSBV) in penaeid shrimps using polymerase chain reaction. Dis Aquat Org 25:133-141

Lotz JM (1992) Developing specific pathogen-free (SPF) animal populations for aquaculture: a case study for IHHN virus of penaeid shrimp. In: Fulks W, Main KL (eds) Diseases of cultured penaeid shrimp in Asia and the United States. The Oceanic Institute, Honolulu, HI, p 258-269

Mari J, Bonami JR, Lightner DV (1993) Partial cloning of the genome of infectious hypodermal and hematopoietic necrosis virus, an unusual parvovirus pathogenic for penaeid shrimps; diagnosis of the disease using a specific probe. J Gen Virol 74:2637-2643

Mari J, Lightner DV, Poulos BT, Bonami JR (1995) Partial 
cloning of the genome of an unusual shrimp parvovirus (HPV): use of gene probes in disease diagnosis. Dis Aquat Org 22:129-134

Murphy FA, Fauquet CM, Bishop DHL, Ghabrial SA, Jarvis AW, Martelli GP, Summers MD (1995) Classification and nomenclature of viruses. Arch Virol (Suppl) 10:1-586

Oste C (1988) Polymerase chain reaction. Biotechniques 6 : $162-167$

Poulos BT, Mari J, Bonami JR, Redman R, Lightner DV (1994) Use of non-radioactively labeled DNA probes for the detection of a baculovirus from Penaeus monodon (PmSNPV=MBV) by in situ hybridization on fixed tissue. J Virol Methods 49:187-194

Sano T, Nishimura T, Oguma K, Momoyama K, Takeno N

Responsible Subject Editor: J. E. Stewart, Dartmouth, Nova Scotia, Canada
(1981) Baculovirus infection of cultured kuruma shrimp, Penaeus japonicus, in Japan. Fish Pathol 15:185-191

Wang $\mathrm{CH}$, Lo CF, Leu JH, Chou CM, Yeh PY, Chou HY, Tung MC, Chang CF, Su MS, Kou GH (1995) Purification and genomic analysis of baculovirus associated with white spot syndrome (WSBV) of Penaeus monodon. Dis Aquat Org 23:239-242

Wongteerasupaya C, Vickers JE, Sriurairatana S, Nash GL, Akarajamorn A, Boonsaeng V, Panyim S, Tassanakajon A, Withyachumnarnkul B, Flegel TW (1995) A nonoccluded, systemic baculovirus that occurs in cells of ectodermal and mesodermal origin and causes high mortality in the black tiger prawn Penaeus monodon. Dis Aquat Org $21: 69-77$

Manuscript first received: May 8, 1996

Revised version accepted: August 28, 1996 